\title{
Engineering Properties of Nagar Parkar Plutonic \& Volcanic Rocks as a Construction Aggregates, District Tharparkar, Sindh Province Pakistan
}

\author{
Mushtaque Ahmed Pathan", Maryam Maira Pathan \\ Centre for Pure \& Applied Geology, University of Sindh, Jamshoro, Sindh, Pakistan \\ Email address: \\ ma.pathan12@yahoo.com (M. A. Pathan) \\ ${ }^{*}$ Corresponding author
}

\section{To cite this article:}

Mushtaque Ahmed Pathan, Maryam Maira Pathan. Engineering Properties of Nagar Parkar Plutonic \& Volcanic Rocks as a Construction Aggregates, District Tharparkar, Sindh Province Pakistan. Journal of Civil, Construction and Environmental Engineering.

Vol. 6, No. 2, 2021, pp. 63-68. doi: 10.11648/j.jccee.20210602.15

Received: May 11, 2020; Accepted: March 26, 2021; Published: April 13, 2021

\begin{abstract}
The purpose of this paper is to study the important engineering properties of the volcanic rocks present with the Nagar Parkar Granites located from Sindh University Campus Jamshoro 5 h 44 min (355.3 km) via Hyderabad - Badin Road and $5 \mathrm{~h} 57 \mathrm{~min}(323.5 \mathrm{~km})$ via Naukot - Mithi Road and Islamkot, the rocks look suitable for pavement and concrete aggregates. Number of standard tests were conductedted. Which included; Specific Gravity, Gradation, Soundness, Particle shape and Surface Texture Absorption Index, Abrasion Resistance, Deleterious Materials,, in addition to moisture content and Fineness modulus. Geologically there are two main components known as Pink Granites and Grey granites on the basis of the plagioclase / orthoclase mineral component. Results of the standard tests depicted that both Pink Granites and Grey Granites samples have different characteristics especially concerning abrasion resistance. After comparing the obtained results with standard specifications showed that both samples can produce aggregates that are suitable for pavement but only Pink sample can produce concrete aggregates. It was also assumed that there should be a technical control in the crushing circuit to produce the required gradation.
\end{abstract}

Keywords: Pink Granite, Construction Aggregates, Grey Granite, Pavement Aggregates, Concrete Aggregates

\section{Introduction}

Aggregate technically is considered as a term for the coarse and fine mineral materials such as sand, gravel and crushed stones that are used with a binding medium (such as Portland cement, water, bitumen, lime, etc.) to form compound materials (such as asphalt concrete and Portland cement concrete. By the total volume, aggregate generally accounts for 75 to 80 percent of hot mixed asphalt (HMA) and about 70 to 80 percent of Portland cement concrete (PCC) [1]. Aggregate is also used for base and sub-base courses for both flexible and rigid pavements [3].

Modern concrete consists of aggregate (fine \& coarse), cement, water, admixture and other additives. Several factors are known to influence the strength of concrete. They include their batch ratios, processes, aggregate texture and shape and nature of other constituent materials [10]. Aggregates are mixtures of various sizes of stone or rock particles in contact with each other. They are typically combinations of gravel and crushed materials, such as limestone, basalt and granite, but may also include blast furnace slag, or recycled concrete fragments. Particles with a diameter greater than $4.75 \mathrm{~mm}$ are usually classified as coarse aggregate, while smaller particles are called fine aggregate [9]. In earlier concept for a long time aggregate was considered to be an inert filler which is added to cement paste simply for economic reasons. [12]

The construction industry utilizes construction aggregates as natural mineral and rock fragments in portland cement concrete, bituminous concrete pavement, road base, construction fill, railroad ballast, riprap for waterway construction, landscaping, and other construction uses for civil structures like brigdes, dams, buildings etc. They are used as an inexpensive and non-reactive constituents in portland cement concrete, road base, and fill materials where 
they take higher portion (bulk) while providing the compressive strength necessary in the final product. (Figure 2)

Like bituminous concrete pavement, construction aggregates provide resistance to creep at increased temperatures, as well as bulk [11]. In portland cement or bituminous concrete pavements, construction aggregates must have the surface properties to allow the natural and chemical cementing materials which keep these products binding. There are some important physical properties required of construction aggregates and their different uses

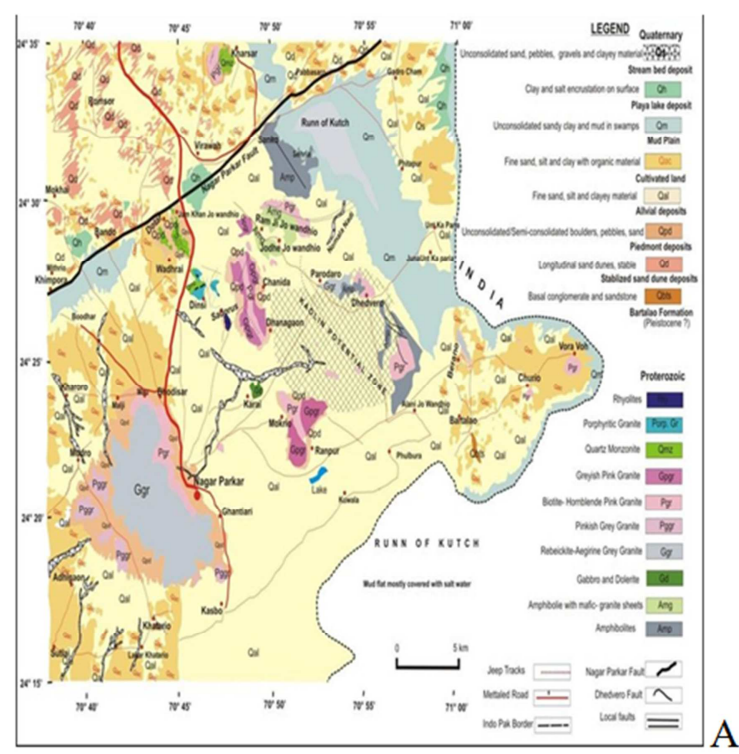

are as bulk unit weight, durability, compressive strength, porosity, permeability, inert chemistry, uniformity of composition, and special features such as shape, color, and texture. The crushed stone and sand and gravel are the natural sources of construction aggregates. Any crushed cement concrete that replaces for natural aggregates must show a similar combination of physical properties required by the end use to compete effectively.

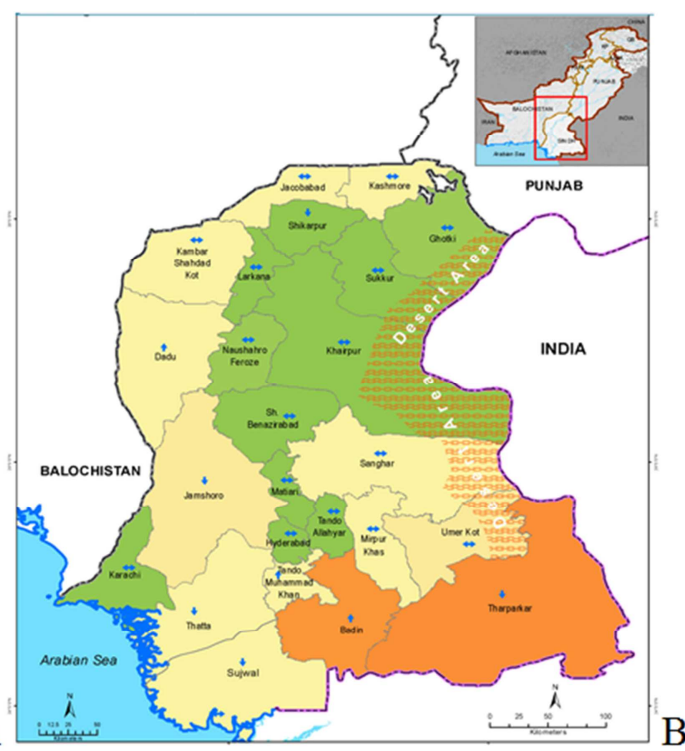

Figure 1. A\&B Geological map of the Nagar Parkar area (bed-rock geology modified after Kazmi and Khan, 1973, Jan et al., 1997, Muslim et al., 1997, Rizvi et al., 2006; Quaternary geology during present work). [13]

Table 1 explains the different types, applications and the standard tests applied for evaluating the produced quarry aggregates. Some of these standard tests are essential for evaluating aggregates application in pavement while others are important to judge the suitability of aggregates in concrete production. From this table it is clear that Aggregate physical properties are the most readily apparent aggregate properties and they also have the direct effect on the performance of the material used as highway construction in pavement from base to wearing course. Whereas, Tables II and III shows Gradation Specifications for Aggregates applied on asphaltic pavement and concrete respectively. [2]

Table 1. Standard tests applied for evaluating the produced quarry aggregates for different applications.

\begin{tabular}{|c|c|c|c|c|c|c|}
\hline \multirow{3}{*}{ ID } & \multirow{3}{*}{ Test } & \multirow{3}{*}{$\begin{array}{l}\text { Applied Standard } \\
\text { (s) }\end{array}$} & \multicolumn{4}{|c|}{ Specification limits and uses } \\
\hline & & & \multicolumn{3}{|c|}{ Asphalt applications as pavement aggregates } & \multirow{2}{*}{$\begin{array}{l}\text { Concrete aggregates } \\
\text { (PCC) }\end{array}$} \\
\hline & & & Sub-base & base & surface & \\
\hline 1 & Absorption Index & ASTM-C 127/128 & Less than $5 \%$ & Less than $5 \%$ & Less than $5 \%$ & $1-2 \% \max$. \\
\hline \multirow{3}{*}{2} & Abrasion Resistance (after & ASTM C131, & Max. loss & Max. loss & Max. loss & Max. loss \\
\hline & $500 \mathrm{rpm})$ & ASTM C535 & $40 \%$ & $45 \%$ & $45 \%$ & $30 \%$ \\
\hline & Deleterious Materials & ASTM D2419/ & Max. $1 \%$ & Max. $1 \%$ & Max. $1 \%$ & Max. $1 \%$ \\
\hline 3 & $\begin{array}{l}\text {-Clay lumps and Friable particles } \\
\text {-Average sand equivalent }\end{array}$ & $\begin{array}{l}\text { ASTM C142 } \\
\text { ASTM C142 }\end{array}$ & From 25 to $35 \%$ & From 25 to $35 \%$ & From 25 to $35 \%$ & From 25 to $35 \%$ \\
\hline 4 & Specific Gravity & ASTM-C 127/128 & $2.55-2.75$ & $2.55-2.75$ & $2.55-2.75$ & More than 2.65 \\
\hline 5 & Gradation & ASTM C136 & & See Table 2 & & See Table 3 \\
\hline \multirow[t]{2}{*}{6} & $\begin{array}{l}\text { Soundness (Magnesium sulfate } \\
\text { based after } 5 \text { cycles) }\end{array}$ & ASTM C88 & Max. loss $30 \%$ & Max. loss $20 \%$ & Max. loss $15 \%$ & Max. loss $12 \%$ \\
\hline & Particle Shape and Surface & ASTM D3398, & & & & \\
\hline \multirow[t]{2}{*}{7} & Texture & ASTM D5821, & & & & \\
\hline & Particle index (Ia) & ASTM C1252 & $6-20 \%$ & $6-20 \%$ & $6-20 \%$ & $6-20 \%$ \\
\hline 8 & Fineness modulus & ASTM C125 & N. A. & N. A. & N. A. & $2.7-3.0$ fine $7-9$ coarse \\
\hline 9 & Moisture Content & ASTM C70 & N. A. & N. A. & N. A. & $* *$ \\
\hline 10 & Rock Drop Test & ASTM C-131 & Less than $5 \%$ & Less than $5 \%$ & Less than $5 \%$ & Less than $5 \%$ \\
\hline
\end{tabular}

**high or law moisture contents are suitable but just only consider needed water for Portland cement concrete design. 
ASTM Volume 04.02 Concrete and Aggregates 2018.

Table 2. Gradation Specifications for Aggregates applied on asphaltic pavement.

\begin{tabular}{|c|c|c|c|c|c|c|}
\hline \multirow{3}{*}{ Sieve Size } & \multicolumn{6}{|c|}{ Percent Passing } \\
\hline & & Sub-base Course & Base Course & & Surface Cours & \\
\hline & & (Grading A)* & $(\text { Grading B })^{*}$ & & $($ Grading F)* & \\
\hline $63 \mathrm{~mm}$ & 2.5-inch & - & 100 & & - & \\
\hline $50 \mathrm{~mm}$ & 2-inch & 100 & $97-100$ & & - & \\
\hline $37.5 \mathrm{~mm}$ & 1.5-inch & $97-100$ & - & & - & \\
\hline $25.0 \mathrm{~mm}$ & 1-inch & - & - & & 100 & \\
\hline $19.0 \mathrm{~mm}$ & 0.75 -inch & - & - & & $97-100$ & \\
\hline $12.5 \mathrm{~mm}$ & 0.5 -inch & - & 40 & $-60(8)$ & & - \\
\hline $4.75 \mathrm{~mm}$ & No. 4 & $40-60(8)$ & & - & & $41-71(7)$ \\
\hline $0.425 \mathrm{~mm}$ & No. 40 & - & $9-17(4)$ & & & $12-28(5)$ \\
\hline $0.075 \mathrm{~mm}$ & No. 200 & $0-12(4)$ & 4 & $-8(3)$ & & $5-16(4)$ \\
\hline
\end{tabular}

*Number in parentheses indicates the allowable deviations () from the target value.

Table 3. Gradation Specifications for aggregates applied on concrete.

\begin{tabular}{|c|c|c|c|c|c|}
\hline \multicolumn{6}{|c|}{ Percentage passing for graded aggregate of nominal size } \\
\hline Sieve size mm & 40 & & $20 \mathrm{~mm}$ aggregates & $16 \mathrm{~mm}$ & $12.5 \mathrm{~mm}$ \\
\hline $80 \mathrm{~mm}$ & 100 & & - & - & - \\
\hline $40 \mathrm{~mm}$ & 95 & & 100 & - & - \\
\hline $20 \mathrm{~mm}$ & 35 & -70 & $95-100$ & 100 & 100 \\
\hline $16 \mathrm{~mm}$ & & - & - & $90-100$ & - \\
\hline $12 \mathrm{~mm}$ & & - & - & - & $90-100$ \\
\hline $10 \mathrm{~mm}$ & 10 & -35 & $25-35$ & $30-70$ & $40-85$ \\
\hline $4.75 \mathrm{~mm}$ & 0 & -5 & $0-10$ & $0-10$ & $0-10$ \\
\hline
\end{tabular}

This paper aims at evaluating some Saudi volcanic rocks, $30 \mathrm{~km}$ to the east of Jeddah city, as pavement and concrete aggregates.

\section{Experimental Work}

The standard tests for the two selected samples were done at Civil Engineering Department, Mehran University of Engineering \& Technology Jamshoro. Figure 1 shows photographs for some of the used facilities. These facilities were used as stated in the required tests standards.

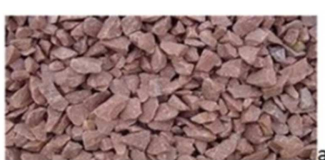

CRUSH AGGREGATE $6.12 .5 \mathrm{~mm}$

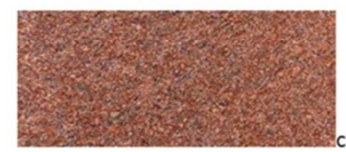

Fine grained Pink Granite

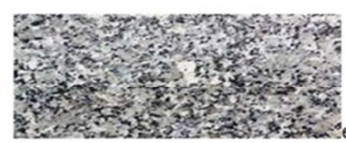

Fine grained grey granite

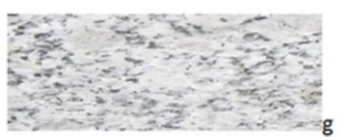

CRUSH AGGREGATE $4.75 .6 .0 \mathrm{~mm}$

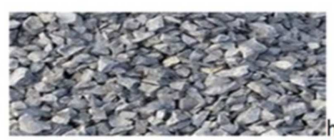

Figure 2. A GRANITE AGGREGATE SAMPLES ( $a, b, c, d, e, f, g, h)$

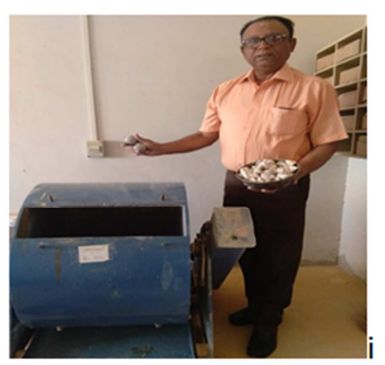

L A TEST

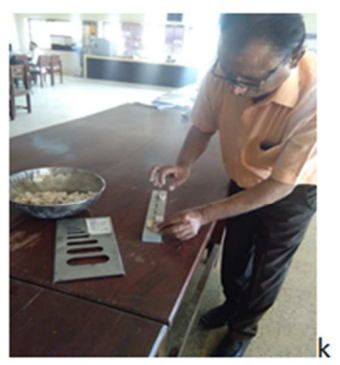

SHAPE TEST

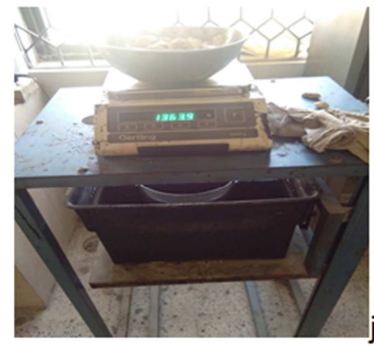

UNIT WEIGHT

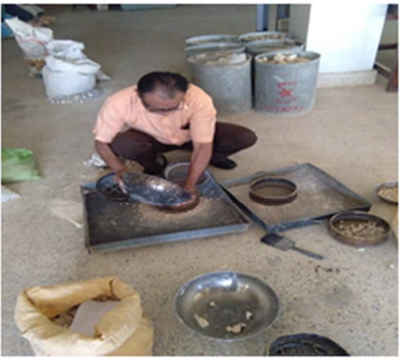

GRADATION TEST
Figure 2. $B(I, j, k, l)$ NAGAR PARKAR GRANITES SAMPLE \& VARIETIES USED IN CONSTRUCTION IN SINDH PAKISTAN.

Photographs for Some of the used facilities to prepare and test the samples.

\section{Results and Discussions}

Geology and Geochemistry

As the Nagar Parkar granites, including the grey granite, 
are conformably lying with the younger ages and creat doubt on the older ages reported by Khan et al [7]. This hence is, confirmed that propinquity, and resemblance in petrography, geochemistry and radiometric dates lead strong support in assuming the Nagar Parkar rocks as portion of the Malani igneous suite. The igneous comlex magmatism has been classified into three phases: (1) bimodal acid and basic volcanics, (2) granite plutons, and (3) felsic and mafic dykes $[8,14]$. On the other hand a couple of rhyolite domes [4], equivalents of the first phase volcanic rocks have not been reported from Nagar Parkar, but they are absent from a consequence of erosion. The Nagar Parkar area comprises many hills, including Kharsar, that are occupied by granitic intrusions and younger dykes. While the eastern part of the Kharsar hill consists of grey-pink granite earlier and the western part by pink granite later. Both of them contain many dykes of microgranite/aplite, rhyolite, and mafic rocks, which are particularly concentrated in a 200 meters wide, NE trending zone passing through the hill. This zone may be a major shear that facilitated repeated empregnation of magmatic sheets. So many of the dykes are small, but a few extend for many hundred meters, single or in composite sheets. The silicic dykes are of more than one generation. Some are older than the pink granite and are related to the grey-pink granite; others are co-related to pink granite. Yet anothers appear to be distinctly younger and contemporaneous with the mafic and rhyolite dykes. It is, thus, observed that the mafic and rhyolitic dykes are a product of bimodal magmatism. Bimodal mafic-felsic magmatism has been reported from moe than one areas. It is likely that under plating of the crust by mafic magma went to partial melting and production of felsic magma. [8] also suggested pouring of the crust by basaltic magma, coupled with extensional tectonics, for bimodal magmatism in Jalor area of Indian Rajhistan.

These different formations are numbered in the Figure as parts from one to four, and formation of each part can be explained as follows:

1. Zone 1, (Part no 1) (Kharsar igneous body of Layered Rocks), is small and mixed of more than one type of rocks (filsic and mafic rocks). It depictsts the south eastern corner of crusher area.

2. Zone 2, (Part no 2) (Talus Deposits) consist of unsorted angular rocks fragments of all sizes in fan -like accumulations this available in the southern western corner of the crusher area.

3. Zone 3, (Part no 3), is a Diorite and Quartz Diorite rock of Precambrian intrusive rocks. It represents majority of crusher area. As a result in evaluating the crusher area a sample was taken from this part for standard tests. The sample has been named as the Pink Granite sample in this study.

4. Zone 4, (Part no 4/ Table 4), is Karoonjhar hill granite of Precambrian intrusive rocks. It consists of monzogranite and granite rocks. It also represents a major part in crusher area. As a result a second sample was taken from this part and was named as Grey Granite sample.

Table 4. Studied area location shown by coordinates of studied area corners.

\begin{tabular}{|c|c|c|c|c|c|c|}
\hline Studied area & & North & & & East & \\
\hline Corner no. & Degree & Minutes & Seconds & Degree & Minutes & Seconds \\
\hline 1 & 24 & 21 & 34.88 & 70 & 45 & 28.258 \\
\hline 2 & 24 & 21 & 34.2 & 70 & 45 & 9.33 \\
\hline 3 & 24 & 21 & 32.68 & 70 & 45 & 5.136 \\
\hline 4 & 24 & 21 & 34.88 & 70 & 45 & 5.1 \\
\hline
\end{tabular}

In assessing the studied area rocks, the pink and grey selected samples were firstly subjected to complete chemical analyses in Advance Research Labs. The obtained results are shown in Table 5. The pink sample in the geochemical analyses report is coded as Q-D-KH2 while the white sample is coded as GKH1. The chemical analyses of the two samples show a partial difference regarding majority of the constituents which implies a different behavior regarding their physical properties and hence their possible uses.
However, major differences marked in the silica content are expected and can be attributed to the different formation conditions for each of the two selected samples. The high silica content of the pink sample is attributed to the presence of finely disseminated quartz in the diorite matrix. This was observed by naked eye in the freshly crushed sample. The obtained chemical analyses make the investigators take the necessary precautions during the standard testing of the samples.

Table 5. Chemical analyses of the rock bodies existing in the studied area.

\begin{tabular}{|c|c|c|c|c|c|c|c|c|c|c|c|}
\hline Constituent, $\%$ & MgO & $\mathrm{Al}_{2} \mathrm{O}_{3}$ & $\mathrm{SiO}_{2}$ & $\mathrm{P}_{2} \mathrm{O}_{5}$ & $\mathrm{CaO}$ & $\mathrm{TiO}_{2}$ & MnO & $\mathrm{Fe}_{2} \mathrm{O}_{3}$ & $\mathrm{Na} 2 \mathrm{O}$ & $\mathrm{K}_{2} \mathrm{O}$ & LOI* \\
\hline Pink Granite sample & 0.42 & 13.42 & 73.23 & 0.05 & 0.28 & 0.83 & 0.07 & 3.99 & 3.66 & 3 & 1.02 \\
\hline Grey Granite sample & 2.33 & 15.56 & 61.63 & 0.27 & 3.32 & 0.72 & 0.1 & 7.68 & 3.44 & 2.71 & 2.23 \\
\hline
\end{tabular}

*Loss on Ignition

Standard tests results

The results of the conducted tests are included in Table 6 and Figure 3 (size distribution or gradation). However, concise summary of these results compared to needed specifications is articulated in the matrix shown in Tables VIIa and VIIb for pink and grey samples respectively. 
Table 6. Results of the standard tests carried out to assess both grey and pink samples as aggregates.

\begin{tabular}{llll}
\hline \multirow{2}{*}{ ID } & Test & Results & White sample \\
\cline { 3 - 4 } & Black sample & 2.177 \\
\hline 1 & Absorption Index & 1.071 & 30.36 \\
2 & Abrasion Resistance (after 500 rpm) & 3.86 & 0.575 \\
& Deleterious Materials & 0.478 & 26.815 \\
3 & Clay lumps and Friable particles & 28.147 & 2.625 \\
& Average sand equivalent & 2.742 & See Figure 3 \\
4 & Specific Gravity & See Figure 3 & 1.8 \\
5 & Gradation as coarse aggregates & 0.96 & 6.85 \\
6 & Soundness (Magnesium sulfate based after 5 cycles) & 15.656 & $3.8 \%$ \\
7 & Particle Shape and Surface Texture (Particle index (Ia)) & $7.6 \%$ & $1.5 \%$ \\
8 & Fineness modulus & $0.550 \%$ & $0.529 \%$ \\
9 & Moisture Contents & $0.521 \%$ & \\
10 & Rock Drop Test & & \\
\hline
\end{tabular}

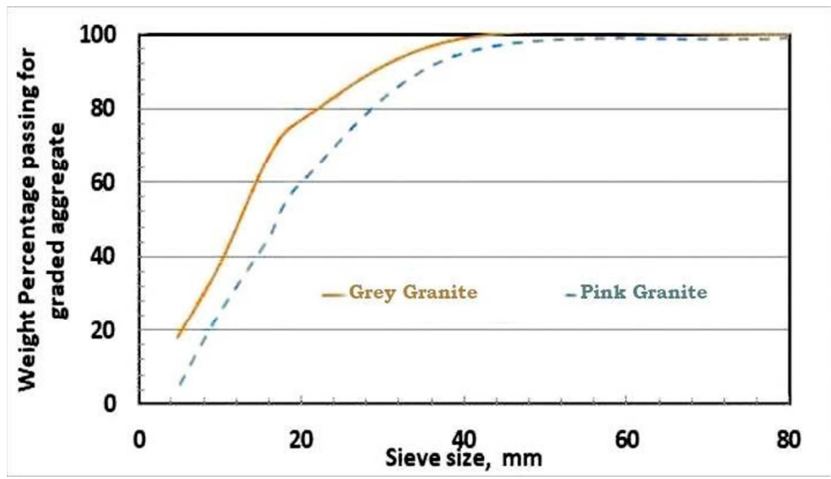

Figure 3. Size distributions for grey and pink samples as coarse concrete aggregates.

From Table 7, it can be seen that the pink sample satisfies all the required specifications to be used as paving or concrete aggregates. Though, some precautions should be taken into consideration for the crusher to work safely. For instance, the abrasion resistance for this sample is $3.86 \%$ which suggests a very abrasive material that is not easy to be crushed using any normal crusher i.e. a special design for the crusher is a must to overcome the high abrasion resistance of the sample. Moreover, the specific gravity of the sample for asphalt applications is considered on the upper border and as a result mixing it with the white sample can give a more suitable blend $[5,6]$. On the other hand, Table 7 shows that the white sample can have a wide range of applications. It fails in application as gravels for PCC due to its low specific gravity (2.625 compared to a minimum needed of 2.65). Blending this sample with the black one may lead to suitable PCC gravel regarding its specific gravity. However, a special design for the crusher is a must to overcome the high abrasion resistance of the black sample some which if not done may lead to unsuitable specifications regarding grading. Due to the wide difference among the two samples, one can recommend to be worked concurrently in a blend to give a more suitable blend of aggregates that achieve the required specifications for both pavement and concrete. Furthermore, a strict crusher operating conditions should be technically monitored to produce required gradation. [9]

Table 7. Standard tests results and possible uses for aggregates produced from black sample.

\begin{tabular}{|c|c|c|c|c|c|c|c|c|c|c|}
\hline \multirow{3}{*}{ ID } & \multirow{3}{*}{ Test } & \multicolumn{9}{|c|}{ Specification limits and possible uses } \\
\hline & & \multicolumn{5}{|c|}{ Asphalt applications as pavement aggregates } & \multirow{2}{*}{\multicolumn{2}{|c|}{$\begin{array}{l}\text { Concrete Aggregates } \\
\text { (PCC) }\end{array}$}} & \multirow{2}{*}{$\begin{array}{l}\text { Black Sample } \\
\text { results }\end{array}$} & \multirow[b]{2}{*}{ Remarks } \\
\hline & & Sub-base & base & \multicolumn{3}{|c|}{ surface } & & & & \\
\hline 1 & Absorption Index & $\sqrt{ }$ & $\sqrt{ }$ & \multicolumn{3}{|c|}{$\sqrt{ }$} & \multicolumn{2}{|c|}{$\sqrt{ }$} & 1.071 & \multirow{3}{*}{$\begin{array}{l}\text { Needs attention in } \\
\text { crusher design }\end{array}$} \\
\hline 2 & $\begin{array}{l}\text { Abrasion Resistance (after } 500 \\
\text { rpm) }\end{array}$ & $\sqrt{ }$ & $\sqrt{ }$ & \multicolumn{3}{|l|}{$\sqrt{ }$} & \multicolumn{2}{|l|}{$\sqrt{ }$} & 3.86 & \\
\hline 3 & $\begin{array}{l}\text { Deleterious Materials Clay } \\
\text { lumps and Friable particles } \\
\text { Average sand equivalent }\end{array}$ & $\begin{array}{l}\sqrt{ } \\
\sqrt{ }\end{array}$ & $\begin{array}{l}\sqrt{ } \\
\sqrt{ }\end{array}$ & \multicolumn{3}{|l|}{$\begin{array}{l}\sqrt{ } \\
\sqrt{ }\end{array}$} & \multicolumn{2}{|l|}{$\sqrt{ } \sqrt{ }$} & 0.47828 .147 & \\
\hline 4 & Specific Gravity & $\sqrt{ }$ & $\sqrt{ }$ & \multicolumn{3}{|l|}{$\sqrt{ }$} & $\sqrt{ }$ & & 2.742 & \multirow{3}{*}{$\begin{array}{l}\text { In asphalt Sp. Gr. Is } \\
\text { in the border limits } \\
\text { See appendix Needs } \\
\text { attention in crushing } \\
\text { circuit }\end{array}$} \\
\hline 5 & Gradation & \multicolumn{2}{|c|}{ See appendix } & & & & \multicolumn{2}{|c|}{ See appendix } & See appendix & \\
\hline 6 & \multicolumn{3}{|c|}{ Soundness (Magnesium sulfate based after 5 cycles) } & $\sqrt{ }$ & $\sqrt{ }$ & $\sqrt{ }$ & $\sqrt{ }$ & 0.96 & Very safe & \\
\hline 7 & \multicolumn{3}{|c|}{ Particle Shape and Surface Texture (Particle index (Ia)) } & $\sqrt{ }$ & $\sqrt{ }$ & $\sqrt{ }$ & $\sqrt{ }$ & 15.656 & \multicolumn{2}{|c|}{ Needs attention in crushing circuit } \\
\hline 8 & \multicolumn{3}{|c|}{ Fineness modulus } & N. A. & N. A. & N. A. & $\sqrt{ }$ & $7.6 \%$ & & \\
\hline 9 & Moisture Contents & & & N. A. & N. A. & N. A. & $\sqrt{ }$ & $0.550 \%$ & \multirow{2}{*}{\multicolumn{2}{|c|}{$\begin{array}{l}\text { Consider needed water for PCC design } \\
\text { Pafe }\end{array}$}} \\
\hline 10 & Rock Drop Test & & & $\sqrt{ }$ & $\sqrt{ }$ & $\sqrt{ }$ & $\sqrt{ }$ & $0.521 \%$ & & \\
\hline
\end{tabular}

$\sqrt{ }$ means suitable for stated application

$\mathrm{x}$ means not suitable for stated application

N. A. means test results is not counted in deciding stated application 


\section{Conclusions}

From the results presented in this research study one can conclude the following:

The studied area consists of a variety of existed volcanic intrusions mainly four different rock formations: Felsic volcanic rocks, Talus Deposits, Quartz Diorite+ diorite and Monzogranite.

Nearly $75 \%$ of the area contains two main formations: Quartz Diorite + diorite (pink sample) and Monzogranite (grey granite sample).

The pink sample satisfies all the required specifications to be used as paving or concrete aggregates with minor specifications being on the border (specific gravity for asphalt applications).

The pink sample is a very abrasive material that is not easy to be crushed using any normal crusher.

The grey sample is different from the pink one and can have a wide range of applications but it fails in application as gravels for PCC due to its low specific gravity $(2.625$ compared to a minimum needed of 2.65).

\section{References}

[1] Ahlrich, R. C., 1996. Influence of aggregate properties on performance of heavy-duty hot-mix asphalt pavements. Transportation Research Record, 1547 (1), pp. 7-14.

[2] ASTM Volume 04.02 Concrete and Aggregates 2018.

[3] Jain, S., Joshi, Y. P. and Goliya, S. S., 2013. Design of rigid and flexible pavements by various methods \& their cost analysis of each method. International Journal of Engineering Research and Applications, 3 (5), pp. 119-123.

[4] Jan MQ, Laghari A, Khan MA (1997) Petrography of the Nagar Parkar igneous complex. Tharparkar, southeastern Sindh, Pakistan. Geol Bull Univ Peshawar 30: 227-259.
[5] Kandhal, P. S. and Lee, D. Y., 1970. An Evaluation of the Bulk Specific Gravity for Granular Materials. Highway research record, (307).

[6] Kandhal, P. S., Khatri, M. A. and Motter, J. B., 1992. Evaluation of particle shape and texture of mineral aggregates and their blends (No. NCAT Report No. 92-4). National Center for Asphalt Technology.

[7] Khan T, Murata M, Rehman HU, Zafar M, Ozawa H (2012) Nagar Parker granites showing Rodinia remnants in the southeastern part of Pakistan. J Asian Earth Sci 59: 39-51.

[8] Kochhar N, Dhar S, Sharma R (1995) Geochemistry and tectonic significance of acid and basic dykes associated with Jalor magmatism, west Rajasthan. Geol Soc India Mem 33: 375-389.

[9] Korkanç, M. and Tuğrul, A., 2004. Evaluation of selected basalts from Niğde, Turkey, as source of concrete aggregate. Engineering Geology, 75 (3-4), pp. 291-307.

[10] Mahmoud, E. and Masad, E., 2007. Experimental methods for the evaluation of aggregate resistance to polishing, abrasion, and breakage. Journal of Materials in Civil Engineering, 19 (11), pp. 77-985.

[11] Meininger, R. C., 1992. Effects of aggregates and mineral fillers on asphalt mixture performance. ASTM.

[12] Mielenz, R. C., 1994. Petrographic evaluation of concrete aggregates. In Significance of Tests and Properties of Concrete and Concrete-making Materials. ASTM International.

[13] Pathan, M. A., Maira, M. and MUET, J., 2018. Geology \& Engineering Properties of Nagar Parkar Granites, District Tharparkar, Sindh, Pakistan. International Journal of Engineering Science, 18640.

[14] Sharma KK (2005) Malani magmatism, an extensional lithospheric tectonic origin. Geol Soc Am Spec Pap 388: 463476. 